\title{
Team Work Essential for Collaborative Care
}

\author{
Shireen Arif* \\ MSN, BScN, RN, RM, Assistant Professor, College of Nursing, Ziauddin University, Pakistan
}

Submission: August 02, 2018; Published: August 07, 2018

*Corresponding author: Shireen Arif, MSN, BScN, RN, RM, Assistant Professor, College of Nursing, Ziauddin University, Pakistan, Tel: 3343853155

; Email: suz83k2000@yahoo.com

\section{Opinion}

The health care providers have to work as a team to provide comprehensive care to the patient, for that all paramedical staff should gather on one place and discuss each and every aspects of the patient. Clinical rounds provide an opportunity for all paramedical staff to discuss each and every aspects of the patient. On my clinical rounds with physician and other doctors I observed that in some wards such as, critical care area, nurses actively participate in the rounds whereas, in some wards such as, general ward nurses were serving as the patient's file holders.This incident stood out for me because as a health team member nurses have toactively participate in the rounds. Nurse is the primary care providers of the patient. As the primary care provider there are many issues related to the patient on daily bases for which nurses always have complaint that doctors are not answering. These issues can be resolved by active participation on clinical rounds. While reflecting these observations many questions revolve around my mind, such as, why nurses are not participating in these rounds? Are they not responsible for patient care or they do not own their responsibilities? Didn't they have any issues to discuss? Last but not least what literature says about the involvement of nurses in the clinical round?.

Larsson et al. [1]highlighted medical rounds are the complex and critical activities which provide opportunity to the multidisciplinary team to come together to review a patient's condition and provide high quality and safe care on timely bases and in relevant manner. So the clinical round offers a possibility for the coordinated care and full engagement for the patient by all the paramedical staff in which nurse's role as a primary care provider. Furthermore, clinical rounds present immense opportunity for effective communication, information sharing and joint learning through active participation of all members of the multidisciplinary team Larsson et al. [1]. Clinical rounds build many abilities in nurses, it enhance nurse's ability to integrate critically and increases the decision making skills related to care of the patient and build confidence to communicate Manias \&
Street [2]. Lees [3] stated that ward rounds are crucial aspects of acute care. The nurses' involvement varies according to their responsibilities and assignments in rounds. Despite of all on nurses have a vital role to play and should make it a priority to attend. Many patients have the expectations from the nurses to play a role of advocator for them Lee [3].

If I reflect back the situation in the critical care area nurses were actively participating in the clinical rounds because they have less number of patients to attend, whereas, in general wards the level of participation was less. Although nurses have many responsibilities to fulfill in a shift, still attending clinical rounds should be one of them. Clinical rounds provide many opportunities to the nurses, such as they could interact and could build their own confidence. Moreover, clinical rounds upgrade nurses with current knowledge.In conclusion clinical round has many benefits for the patients and for the nurses as well but there is a need to activate nurses to participate in these rounds. Nurse Managers should take serious notice on this issue and review policies hospital to make nurses to attend clinical rounds as the compulsory tasks for the nurses. Furthermore there is need to arrange in-service session for nurses to build their confidence and to teach various ways to develop good communication skills among them. This session helps nurses to overcome their weaknesses and participate in clinical rounds which ultimately results in providing collaborative care to the patient.

\section{References}

1. Manias E, Street A (2001) Nurse doctor interactions during critical care ward rounds. Journal of Clinical Nurse 10 (4): 442 - 450.

2. Larsson I E, Sahlsten, M J M, Segesten K, Plos K A. E (2011). Patients' perceptions of nurses' behavior that influence patient participation in nursing care: A critical incident study. Nursing Research and Practice 11(1): $1-8$

3. Lees L (2013) The nurse's role in hospital ward rounds. Nursing Times 109(12): $12-14$. 

(C) (P) This work is licensed under Creative

BY DOI: 10.19080/JOJNHC.2018.09.555756

\section{Your next submission with Juniper Publishers will reach you the below assets}

- Quality Editorial service

- Swift Peer Review

- Reprints availability

- E-prints Service

- Manuscript Podcast for convenient understanding

- Global attainment for your research

- Manuscript accessibility in different formats ( Pdf, E-pub, Full Text, Audio)

- Unceasing customer service

Track the below URL for one-step submission https://juniperpublishers.com/online-submission.php 